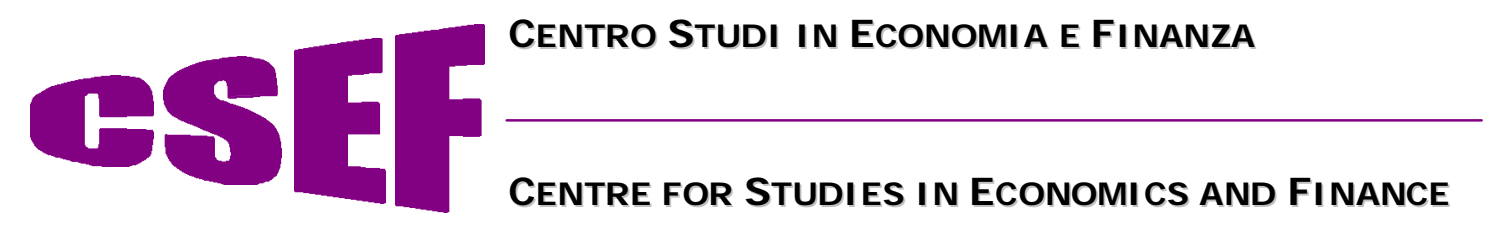

WORKING PAPER no. 7

\title{
Superior Information, Income Shocks and the Permanent Income Hypothesis
}

\author{
Luigi Pistaferri
}

September 1998 


\title{
WORKING PAPER no. 7
}

\section{Superior Information, Income Shocks \\ and the Permanent Income Hypothesis}

\author{
Luigi Pistaferri ${ }^{1}$
}

\begin{abstract}
According to the permanent income hypothesis with quadratic preferences, savings should react only to transitory income shocks, but not to permanent shocks. The problem is that income shock components are not separately observable. I show how the combination of income realizations with subjective expectations can help to identify separately the transitory and the permanent shock to income, thus providing a powerful test of the theory. The empirical analysis is performed on a sample of Italian households drawn from the 1989-1991 Survey of Household Income and Wealth.
\end{abstract}

KEYWORDS: Subjective expectations, income shocks, permanent income hypothesis.

JEL Classification: E21; D84; D91.

1 University College London and Istituto Universitario Navale, Napoli.

I would like to thank Orazio Attanasio, Victoria Chick, Costas Meghir, Jonathan Parker and seminar participants in Tilburg. I am particularly grateful to Tullio Jappelli for providing very detailed comments on a preliminary version of this work. All errors are mine. Financial support from the Italian Ministry of Universities and Scientific Research (MURST) is gratefully acknowledged. 


\section{Table of contents}

1. Introduction

2. The estimation strategy

2.1. Decomposing income shocks in the permanent and the transitory component

2.2. The effect of transitory and permanent income shocks on consumption

2.3. Identification

2.4. Consistency

2.5. Testing for quadratic preferences

3. The data

4. The empirical distribution of the income shocks

5. Empirical results

6. Conclusions

References 


\section{Introduction}

According to the textbook version of the permanent income hypothesis $(\mathrm{PIH})$, household consumption responds on a one-to-one basis to permanent income shocks but is nearly insensitive to transitory income shocks. Equivalently, households save for a rainy day the transitory component of the income innovation and consume entirely the permanent one. Yet, testing for the separate effect of income shocks on consumption or saving is difficult. The main problem is that while the agent may be able to discriminate between a transitory and a permanent shock, the econometrician is not. As a result, econometric identification of separate income shock components remains infeasible. ${ }^{2}$

In this paper I show that combining subjective income expectations with income realizations can help to identify separately the transitory and the permanent shock to income. This has two main advantages. First, it allows to examine the cross-section distribution of separate income shocks; second, it provides a powerful test of the theory. ${ }^{3}$ In particular, I test whether households "save for a rainy day" using data available for a sample of Italian households drawn from the 1989-1991 Bank of Italy Survey of Household Income and Wealth (SHIW).

My estimation strategy has two advantages vis-à-vis previous empirical studies. First, once income shocks become separately identifiable the consistency of empirical estimates does not rely on a long time-series of observations for each individual, a problem that plagues most of the empirical studies. Second, the direct observability of the individual's superior information set minimizes the problem of low power of the instruments used to test the theory.

To assess the validity of the PIH, I regress savings on income shocks. If the theory is true, only transitory shocks should explain saving. However,

2 Attempts in the direction of estimating the separate effect of transitory and permanent income shocks on consumption include Hall and Mishkin (1982) on PSID data, and Flavin (1981) on aggregate US data.

3 Campbell (1987) shows that it is still feasible to test whether households save "for a rainy day" by replacing the information set available to the agent by that available to the econometrician. While consistent under some regularity conditions (see the discussion in Deaton, 1992a, and Flavin, 1993), estimates based on the econometrician's information set are inefficient. 
households "save for a rainy day" only if they display quadratic preferences; if preferences admit prudence, precautionary saving can represent a likely source of failure of the theory. In fact, the estimates of the effect of income shocks on saving will be inconsistent if the omitted higher moments of the distribution of income shocks are correlated with their realization. But this also suggests that one might test for the deviation from the certainty equivalence assumption augmenting the "saving for a rainy day" equation with the variance term: if the PIH with quadratic preference is true, the variance should not explain saving.

The rest of the paper is organised as follows. Section 2 presents a formal decomposition of the income innovation into a permanent and a transitory component and shows how subjective expectations of income can help to identify separately the two components and provide a test of the PIH. Section 3 presents the data used in this study, while in section 4 I examine the empirical distribution of shocks. Section 5 presents the results of the empirical analysis. When heterogeneity in income growth is ignored, the evidence is supportive of the PIH with a precautionary motive for saving. In particular, savings do respond to transitory income shocks, but also to permanent income shocks and higher moments of the distribution of earnings. However, when heterogeneity is accounted for, the results are not literally consistent with the PIH. In particular, the effect of transitory shocks on saving is much tinier, a finding than can be reconciled with high real interest rates or with the existence of binding liquidity constraints affecting a sizeable proportion of the population. Section 6 concludes. ${ }^{4}$

\section{The estimation strategy}

In this section I show how to decompose income shocks into a transitory and a permanent component, and how to determine their separate effect on saving using the "saving for a rainy day" equation (Campbell, 1987). I also discuss identification and consider some extensions.

An Appendix available upon request contains the wording of the survey question and the procedure I adopted to construct the variables used in the empirical analysis. 
2.1. Decomposing income shocks in the permanent and the transitory component

Suppose current income ${ }^{5}$ admits the following decomposition (as in Muth, 1960, and Blundell and Preston, 1998):

$$
y_{i t}=p_{i t}+\varepsilon_{i t}
$$

where $p_{i t}$ is the permanent component of income and $\varepsilon_{i t}$ a transitory shock. For the sake of simplicity, I assume that the latter is i.i.d. with constant variance $\sigma_{\varepsilon}^{2}$. Permanent income follows a random walk process of the form:

$$
p_{i t}=p_{i t-1}+u_{i t}
$$

where $u_{i t}$ is the permanent shock; this is assumed to be i.i.d. with constant variance $\sigma_{\mathrm{u}}^{2} \cdot{ }^{6} \mathrm{I}$ also assume that the transitory and the permanent shocks are orthogonal to each other at all leads and lags. Combining equations (1) and (2), one obtains:

$$
\Delta y_{i t}=u_{i t}+\Delta \varepsilon_{i t}
$$

where $\Delta$ is the first-difference operator.

5 The measure of income that would be more appropriate to test the PIH is disposable family income net of asset income.

6 The assumption of constant variance for both the transitory and the permanent income shock can be removed without altering the estimation strategy. 
2.2. The effect of transitory and permanent income shocks on consumption

It is worth elaborating on the effect of transitory and permanent income shocks on savings. As shown by Campbell (1987), under stringent assumptions concerning preferences and technology (in particular, quadratic preferences, intertemporal separability, infinite horizon, a rate of intertemporal discount set equal to the real interest rate, and the absence of credit market imperfections), one obtains the following saving "for a rainy day" equation:

$$
S_{i t}=-\sum_{\tau=1}^{\infty} \frac{1}{(1+r)^{\tau}} E\left(\Delta y_{i t+\tau} \mid \Omega_{i t}\right)
$$

which implies that savings mirror the present discounted value of expected income declines. Using the income process (1)-(2), equation (4) simplifies to:

$$
s_{i t}=\frac{1}{1+r} \varepsilon_{i t}
$$

The implications one derives from equation (5) are well known: permanent shocks do not matter (because under the conditions above the optimal rule is to consume them all), and only transitory income shocks explain saving. Provided transitory and permanent income shocks were separately identifiable, one could implement the following regression:

$$
s_{i t}=\beta_{0}+\beta_{1} \text { transitory shock } \text { tit }+\beta_{2} \text { permanent shock }_{i t}+\text { error term }_{i t}
$$

where the error term reflects measurement errors in saving, and test whether $\beta_{1} \cong 1$ and $\beta_{2}=0$. This is the main implication of the PIH I will test in the empirical analysis. Tests of the "saving for a rainy day" based on 
microeconomic data have been performed, among others, by Deaton (1992a) and Alessie and Lusardi (1997). ${ }^{7}$

\subsection{Identification}

Let's define $E\left(x_{i t} \mid \Omega_{i t-1}\right)$ the subjective expectation of $x_{i t}$ given the individual's information set at time $t-1 .^{8}$ It is worth pointing out that $\Omega_{i t-1}$ is the set of information possessed at individual level; the econometrician's information set is generally less rich. Using equation (3) and the assumption of rational expectations, the transitory shock at time $t$ can be exactly identified by:

$$
\varepsilon_{i t}=-E\left(\Delta y_{i t+1} \mid \Omega_{i t}\right)
$$

Using equations (3) and (7), the permanent shock at time $t$ is exactly identified by the expression:

$$
u_{i t}=\Delta y_{i t}-E\left(\Delta y_{i t} \mid \Omega_{i t-1}\right)+E\left(\Delta y_{i t+1} \mid \Omega_{i t}\right)
$$

e.g., the income innovation at time $t$ adjusted by a factor that takes into account the arrival of new information concerning the change in income between $t$ and $t+1$. Thus, given the income process (1)-(2), the transitory and the permanent shock to income can always be identified provided one observes, for at least two consecutive time periods, both the conditional

7 In both cases the authors had available short panels (2 years in Deaton and 3 years in Alessie and Lusardi). Thus their estimates are likely to suffer from the problem of inconsistency firstly remarked by Chamberlain (1984), even if aggregate shocks are controlled for.

8 Throughout, it is assumed that individual agents form rational expectations. 
expectation and the realization of the variable of interest (disposable family income, say). This is unthinkable in the presence of realization data only. ${ }^{9}$

The 1989 and 1991 SHIW data provide a unique opportunity to perform the tests of the PIH implied by equation (6). However, a problem with the SHIW data is that they are not available for consecutive years, but only at two-year intervals; moreover, subjective expectations stretch over a single calendar year (see section 3 for more details). More precisely, the SHIW data provide information on $y_{i t}, y_{i t-2}, \quad s_{i t}, s_{i t-2}, \quad E\left(\Delta y_{i t-1} \mid \Omega_{i t-2}\right)$ and $E\left(\Delta y_{i t+1} \mid \Omega_{i t}\right)$, with $t=1991$. It can be seen that, given equations (7) and (8), the following expressions: $-E\left(\Delta y_{i t+1} \mid \Omega_{i t}\right)=\varepsilon_{i t}, \quad-E\left(\Delta y_{i t-1} \mid \Omega_{i t-2}\right)=\varepsilon_{i t-2}$, and $\left(y_{i t}-y_{i t-2}\right)-E\left(\Delta y_{i t-1} \mid \Omega_{i t-2}\right)+E\left(\Delta y_{i t+1} \mid \Omega_{i t}\right)=\left(u_{i t}+u_{i t-1}\right)$ identify the transitory shock at time $t$, the transitory shock at time $t-2$, and the sum of the permanent shocks at time $t$ and $t-1$, respectively. ${ }^{10}$ Since under the null of the PIH savings depend only upon transitory innovations, that is all we need to implement the estimation of equation (6).

\subsection{Consistency}

The consistency of the saving equation estimates relies on a large crosssection dimension, rather than on a large time-series dimension, as is usually

9 Note that the identification of the income shocks carries over exactly as in equations (7) and (8) if income in levels includes fixed unobservable heterogeneity, i.e. if: $y_{i t}=\lambda_{i}+p_{i t}+\varepsilon_{i t}$. This is because income shocks are identified from income changes. This also implies that $\varepsilon_{i t}=-E\left(\Delta y_{i t+\tau} \mid \Omega_{i t}\right)$ for all $\tau>0$, as future transitory and permanent shocks have all mean zero. The identification strategy is also robust to an income process of the form: $y_{i t}=g_{i t}+m_{t}+p_{i t}+\varepsilon_{i t}$, where $g_{i t}$ and $m_{t}$ capture stochastic life-cycle and business-cycle effects, respectively (i.e., $E\left(g_{i t+\tau} \mid \Omega_{i t}\right)=E\left(m_{t+\tau} \mid \Omega_{i t}\right)=0$ for all $\tau>0)$. In this case, it is easy to show that: $s_{i t}=(1+r)^{-1}\left(g_{i t}+m_{t}+\varepsilon_{i t}\right)$. The subjective expectation $-E\left(\Delta y_{i t+1} \mid \Omega_{i t}\right)$ would now identify the composite error term $\left(g_{i t}+m_{t}+\varepsilon_{i t}\right)$, with the permanent shock still identified by equation (8). A regression of $s_{i t}$ on the subjective expectation $-E\left(\Delta y_{i t+1} \mid \Omega_{i t}\right)$ would still provide us with an estimate of the marginal propensity to save out of a transitory shock to income, the structural parameter we are interested in. Note also that deterministic life-cycle effects can be easily accommodated by noting that $a g e_{i t+\tau}=a g e_{i t}+\tau$.

10 It turns out that if transitory shocks are serially correlated, subjective expectations no longer identify income shocks. This is my main identifying assumption. 
required. This is simply because we do observe the innovation in savings. Indeed, under the null hypothesis of the PIH, the residual term of equation (6) is assumed to reflect only (additive) measurement errors in saving. Hence, the consistency of my estimates rests only on the weak assumption that the cross-section dimension of the sample is large and that measurement errors in saving are not correlated across individuals in the cross-section. These are, of course, weaker conditions than the ones usually required in tests of the Euler equation or of the PIH. Indeed, the availability of income expectations makes practically irrelevant Chamberlain's critique (1984). ${ }^{11}$

\subsection{Testing for quadratic preferences}

If we relax the assumption of quadratic preferences, there is no longer a closed form solution for consumption or savings. Moreover, the error term of the untractable saving equation will contain higher moments of the distribution of income shocks that are likely to be correlated with their realizations; if this is the case, estimates will prove inconsistent. But this also suggests that one can test for the validity of the quadratic preferences assumption by augmenting the "saving for a rainy day" equation by higher moments of the distribution of income; under the null hypothesis of the PIH with quadratic preferences, higher moments should not explain saving. ${ }^{12}$

\section{The data}

I estimate various versions of the "saving for a rainy day" equation using the 1989-1991 panel section of the Bank of Italy Survey of Household Income and Wealth (SHIW). One of the main features of this data set is that

11 Chamberlain's critique states that optimization errors average out over time but not necessarily across households in a cross-section. In Pistaferri (1998) I test for the relevance of Chamberlain's critique by noting that under the null of the PIH I do observe the innovation in savings. This allows the calculation of the empirical covariance between the latter and lagged instruments.

12 Note that a regression of savings on the transitory shock and the conditional variance of income can be seen as a generalization of Caballero's model (1990) with CARA preferences. 
it collected subjective information on future income in both 1989 and 1991. ${ }^{13}$ The 1989 and 1991 SHIW have been used by Guiso, Jappelli and Terlizzese (1992) and Jappelli and Pistaferri (1997) to test various hypothesis related to the life-cycle permanent income hypothesis.

Several surveys contain subjective income expectations, but vary considerably as to the way expectations are elicited. In the case of the SHIW, in 1989 and 1991 each labour income and pension recipient interviewed was asked to attribute probability weights, summing to 100 , to given intervals of inflation and nominal income increases one year ahead.

A problem with these data is that subjective expectations are not reported as for 1989 (1991), but in the following year, usually between March and September, although income, consumption and wealth data refer to the previous calendar year. The reason is that previous experience has shown that people report income more accurately when filing the income tax forms, which must be returned by May 31. I thus need to assume that people do not update their information set between the end of 1989 (1991) and the date of the interview, or that their updating does not affect subjective expectations of income. This can be a strong assumption if people receive important news about the evolution of their future income between the end of 1989 (1991) and the date of the interview; ${ }^{14}$ the problem is somewhat less serious if one recalls that in Italy labour contracts are renewed in the Fall (usually between October and December).

Note that people report one-year-ahead expectations referring to the rate of growth of their earnings; to obtain the one-year-ahead expectations of changes in earnings that would identify the transitory earnings shocks, I simply solve for the expected change in earnings. Given the assumptions on the timing of the expectations, the computation of the latter is simple. First, I define: $E\left(G y_{i t, t+1} \mid \Omega_{i t}\right)$, the expected growth rate of income between year $t$ and year $t+1$ (where $t=1989$ or 1991). Note that this rate is defined in real terms. Then, I derive: $E\left(\Delta y_{i t+1} \mid \Omega_{i t}\right)=y_{i t} E\left(G y_{i t, t+1} \mid \Omega_{i t}\right)$.

Although each labour income recipient is asked to answer the survey question, I rely only on the information provided by the head of the

13 Subjective expectations are also asked in the 1995 SHIW, but differ quite radically from those I use in this paper.

14 The same assumption has been made implicitly in all the papers quoted in this section. 
household or, if the latter are lacking, on those provided by the spouse. The reason is that in most cases information on income recipients other than the head or spouse is lacking. ${ }^{15}$

\section{The empirical distribution of the income shocks}

Table 1 allows to examine the cross-section distribution of income shocks for the sample that includes heads or spouses (1,102 households). ${ }^{16}$ For the sake of comparison, income shocks are divided by current earnings; hence, they can be interpreted in relative terms. Since we have only available the sum of permanent shocks in 1990 and 1991, the figures in the first column should be read as the ratio of average permanent shock between 1990 and 1991 and earnings in 1991. The next two columns focus on the relative transitory shocks in 1991 and 1989, respectively.

In 1991 average earnings featured a negative innovation of about 1.3 percent in real terms; the decomposition into transitory and permanent shocks, however, shows that while the permanent component plays a negative role ( -4.5 percent on average), the transitory shock is positive $(+3.2$ percent on average $)$.

Permanent shocks are negative for all population groups; however, the effect is stronger for the self-employed, the middle aged, the more educated, and the poor (as measured by family income quartiles). As for the transitory shocks in 1991, these are higher for those approaching the retirement, with few years of schooling, and living in the north. While still positive on average, the transitory earnings shock in 1989 is not as large as in 1991 (1.4 percent vis-á-vis 3.2 percent), and it is even negative for few population groups (the very young and the most educated).

An average permanent shock of -4.5 percent is not negligible. On the other hand, there is an increasing body of evidence (Miniaci and Weber, 1996; Bertola and Ichino, 1996) showing that in the early 1990s Italian

15 In other words, I regress saving on the head's earnings shocks, rather than on the shocks referring to disposable family income.

16 For 95 percent of our sample, we use information directly pertaining to the head of the household. 
households perceived a negative permanent change in their lifetime income. This was due to various reasons: radical political changes, pay freezing in the public sector that spread to the private sector through income policy experiments, increasing taxation aimed at meeting the Maastricht Treaty criteria, pension and labour market reforms, etc.

In particular, in 1991 the wage indexation clause (scala mobile) was abolished and the laws regulating the hiring process were dramatically renewed with the aim of relaxing labour market regulations. It has been argued that the former had the effect of increasing earnings inequality after decades of compression in the earnings differentials, while the latter had the effect of increasing earnings uncertainty because of job instability (Bertola and Ichino, 1996).

The income policy experiments were introduced as transitory measures aimed at freezing pay rise after years of unnecessary adjustments; ex post, some of these measures seem to have permanently reduced wages' purchasing power.

In our context, pension reforms can be important to an extent that depends on how much the prospective income power of those who are currently working is affected. Due to the unprecedented unbalance between contributors and beneficiaries in the Italian pay-as-you-go social security system, both the Amato and the Dini reforms (the two main reforms implemented in the early 90s, named after the prime ministers who signed them) went in the direction of cutting future benefits and increasing contributions.

Finally, labour market and pension reforms were accompanied by an increase in taxation. The population group that is likely to have suffered more from the introduction of new fiscal measures is the self-employed. In particular, the self-employed were hit by the introduction of a minimum tax, which based tax payments on the presumption of a minimum annual income. The radical changes in political attitudes towards tax noncompliance and the introduction of stricter measures for tax enforcement might have contributed to strengthen the perception of a decline in the permanent income for this group.

A final remark is that we only observe a snapshot of the distribution of earnings shocks in 1989 and 1991; a thorough analysis of how people form and change their expectations in the face of idiosyncratic and aggregate events would require a longer period of observations, which would ease the task of disentangling life-cycle from business-cycle related shocks. 
Unfortunately, subjective expectations are rarely asked in survey data, and in the case of the SHIW, they were asked in the format used in this paper only in 1989 and 1991.

\section{Empirical results}

Table 2 presents the result of estimating the "saving for a rainy day" equation for the sample of heads and spouses (1,102 households). We estimate three basic regressions: (i) the one implied by equation (5), with only the transitory income shock included as an explanatory variable, and then including separately: (ii) the permanent income shock, and (iii) the conditional variance of income. The latter can be easily derived from the data on subjective expectations. Note that the OLS regressions for specifications (i) and (iii) can be estimated for both 1989 and 1991 as they do not involve lagged variables; thus in these cases the sample size is twice as large as the one for specification (ii). OLS estimates for the three models above are presented in columns (1)-(3) of table 2. I trim the sample at the bottom and top percentile of the distribution of saving to avoid my estimates being contaminated by influential outliers. Standard errors are robust to the presence of heteroscedasticity of unknown form. Saving is defined as the difference between family disposable income and non-durable consumption; I also experimented defining saving as the difference between family disposable income and total consumption and found no appreciable difference in the pattern of results.

The results of estimating equation (5) are supportive of the PIH with rational expectations. Column (1) shows that savings strongly react to transitory income shocks (a point estimate of 0.71 ). The hypothesis that the propensity to save out of a transitory earnings shock is one has a $p$-value of 27 percent. The null hypothesis that the coefficient on the transitory shock equals $(1+r)^{-1}$ was also tested by considering a grid of possible values for the real interest rate ranging from 0 to 10 percent $;{ }^{17}$ in no case did I reject the null hypothesis.

17 The average real interest rates in 1991 were: 0.58 percent (deposits), 5.58 percent (Treasury bonds), and 4.32 percent (other assets, including shares). Interest rates in 1989 were very similar to those for 1991 . 
In column (2) I add to the main specification in levels the sum of the permanent income shocks in periods $t$ and $t-1$. This raises the problem that we cannot separately identify the effect of the permanent shocks at two different dates. The problem can be handled by noting that under the null hypothesis of the PIH with quadratic preferences both coefficients are zero, and so should be the coefficient attached to the sum of the current and past permanent income shocks. The results show that the null hypothesis is rejected: permanent income shocks are significant predictors of household savings. Nevertheless, the size of the coefficient is tiny: the null hypothesis that the transitory shock and the permanent shock equally affect savings is strongly rejected (a $p$-value of 0.32 percent). Taken at face value, these results suggest that households save not only the transitory income shocks in their entirety, but also a sizeable portion of their permanent shocks. Therefore, the certainty equivalence model seems to fail in the sense of predicting saving rates that are too low (in absolute value) with respect to the available evidence.

Yet, too much savings can be reconciled with the existence of a precautionary motive for saving. A piece of evidence strongly in support of the latter is reported in column (4); here I include the conditional variance of head's earnings ${ }^{18}$ alongside the transitory shock. The version of the PIH I have tested so far might fail because preferences are not quadratic. If individual preferences admit a positive third derivative (e.g., if consumers are prudent in the sense clarified by Kimball, 1992), the estimates of the saving for a rainy day equation are inconsistent because of the omission of higher moments of the distribution of income shocks that are correlated with the cross-section mean of the transitory shock. The test I conduct is simple. Under the null of the PIH with quadratic preferences, higher moments of the distribution of earnings should not matter. The hypothesis is rejected: the conditional variance of earnings ${ }^{19}$ has the expected sign (more uncertainty should in fact increase current saving) and is statistically significant, thus suggesting that the assumption of quadratic preferences is inappropriate.

19 This is defined as $\operatorname{var}\left(y_{i t+1}-y_{i t} \mid \Omega_{i t}\right)=\operatorname{var}\left(y_{i t+1} \mid \Omega_{i t}\right)$. Note that we cannot distinguish between the variance of the transitory shock and the variance of the permanent shock. The variance term is obtained from the conditional variance of the rate of growth of future earnings by noting that: $\operatorname{var}\left[\left(y_{i t+1}-y_{i t}\right) / y_{i t} \mid \Omega_{i t}\right]=y_{i t}^{-2} \operatorname{var}\left(y_{i t+1}-y_{i t} \mid \Omega_{i t}\right)$. 
This conclusion is supported by previous empirical evidence available from Italy (Guiso, Jappelli and Terlizzese, 1992; Jappelli and Pistaferri, 1997).

To confirm the robustness of my findings, I have re-estimated the saving for a rainy day equation by accounting for preference heterogeneity. In particular, I assume that the bliss point of household utility is a function of age, age squared and family size. Results are presented in table 3, columns (1) to (3). As is clear, the results are not much affected by the introduction of bliss point heterogeneity.

I have also experimented excluding the elderly (those aged more than 65 , the standard retirement age for males) and the self-employed. The reason to exclude the elderly is that the decomposition of income shocks between a transitory and a permanent shock is possibly no longer valid for the retired or those approaching the retirement; the reason to exclude the self-employed is that, as reported by Brandolini and Cannari (1994), they tend to understate or misreport their current earnings; moreover, for this group is more difficult to separate labour income from asset income. The results obtained from excluding these two groups are presented in table 4. It is worth noting that the magnitude of the various effects is not much affected by such exclusions; on the other hand, the precision of the estimates suffers from keeping out either population group.

Heterogeneity in savings may also arise from unobservable individual effects in the income process. Suppose to rewrite equation (3) as:

$$
\Delta y_{i t}=u_{i t}+\Delta \varepsilon_{i t}+\phi_{i}
$$

where $\phi_{i}$ is an idiosyncratic deterministic trend in the income process. ${ }^{20}$ Given equation (9), the "saving for a rainy day" equation rewrites:

$$
s_{i t}=\frac{1}{1+r} \varepsilon_{i t}+\lambda_{i}+v_{i t}
$$

\footnotetext{
${ }^{20}$ See Blundell and Preston (1997) for details on the assumptions generating the income process (9).
} 
where $\lambda_{i}=r^{-1} \phi_{i}$, and $v_{i t}$ is a measurement error in savings. The presence of unobservable fixed heterogeneity in the saving function might invalidate simple least squares estimates, in particular if $E\left(\varepsilon_{i t} \phi_{i}\right) \neq 0$. However, firstdifferences estimates are still consistent because the individual effect is washed out when transforming the data. ${ }^{21}$

In columns (4) and (5) of table 2 we present the results of estimating equation (10) by first-differences. Accounting for heterogeneity leads to different conclusions as far as the saving function is concerned. As shown in column (4), the saving equation display point estimates that are much lesser than those in column (1). The effect of the transitory shock is now only 0.45 (with a robust standard error of 0.22 ). In columns (5), we present the results of controlling for both the unobservable heterogeneity and the conditional variance of earnings. Here again, the results are against the certainty equivalence model, confirming the practical importance of the heterogeneity in the income process and the precautionary motive for saving. The specification tested in columns (4) delivers point estimates that are not literally consistent with the PIH. In particular, the PIH implied by equation (5) is consistent only with interest rates of about 30 percent in real terms. A possible explanation is that agents discount the future at rates higher than the ones prevailing in the credit market as a device to reduce the uncertainty related to future resources. ${ }^{22}$

However, a modest effect of transitory shocks on saving may hide binding liquidity constraints. Flavin (1993) proposes the consumption function to be written as:

$$
c_{i t}=y_{i t}^{P}+\gamma\left(y_{i t}+r a_{i t}-y_{i t}^{P}\right)
$$

\footnotetext{
${ }^{21}$ Note that, from income process (9), subjective expectations no longer identify exactly the transitory income shock, because: $E\left(\Delta y_{i t+1} \mid \Omega_{i t}\right)=-\varepsilon_{i t}+\phi_{i}$. However, in order to estimate (10) in firstdifferences, we only need to identify the change in the transitory income shock, which is provided by first-differencing the subjective expectations, i.e., from: $E\left(\Delta y_{i t+1} \mid \Omega_{i t}\right)-E\left(\Delta y_{i t-1} \mid \Omega_{i t-2}\right)=-\left(\varepsilon_{i t}-\varepsilon_{i t-2}\right)$.

${ }^{22}$ Similar results are obtained when preference heterogeneity is accounted for (see columns (4) and (5) of table 3), although estimates are slightly less precisely measured.
} 
where $y_{i t}^{P}=\frac{r}{1+r} a_{i t}+\frac{r}{1+r} \sum_{\tau=0}^{\infty} \frac{1}{(1+r)^{\tau}} E\left(y_{i t+\tau} \mid \Omega_{i t}\right){ }^{23}$ According to Deaton (1992a), the parameter $\gamma$ represents "the extent to which consumption responds to current income over and above the amount that is warranted by the PIH". Thus, the finding that $\gamma>0$ can be interpreted as a symptom of liquidity constraints, as liquidity constrained households can increase their consumption only when income is directly available. It is easy to show that, using (11), the "saving for a rainy day" equation rewrites:

$$
s_{i t}=-(1-\gamma) \sum_{\tau=1}^{\infty} \frac{1}{(1+r)^{\tau}} E\left(\Delta y_{i t+\tau} \mid \Omega_{i t}\right)
$$

and then, using again the income process (9), that:

$$
s_{i t}=\frac{1-\gamma}{1+r} \varepsilon_{i t}+\lambda_{i}
$$

where $\lambda_{i}=-(1-\gamma) r^{-1} \phi_{i}$. A positive $\gamma$ is consistent with the estimates in first-differences reported in columns (4). With a real interest rate of 5 percent, say, $\gamma$ is roughly 0.5 , implying that liquidity constraints are likely to be playing an important role. ${ }^{24}$ Given the severe imperfections of the Italian credit markets by the standards of other industrialised countries and the pervasiveness of various liquidity constraints, particularly in the mortgage market (Guiso, Jappelli and Terlizzese, 1994), this result does not come as a surprise.

23 This term is usually dubbed as "permanent income" (Deaton, 1992b). I will not use such terminology, because here permanent income is given by the expression (2), i.e. it reflects the "normal" labour income available to an individual throughout her working career.

${ }^{24}$ The magnitude of this coefficient is very similar to that obtained when testing for excess sensitivity on time series data. Recall that under the null of the PIH with quadratic preferences, estimates based on time series data are consistent (because of the large $T$ argument) and do not suffer from aggregation bias. 


\section{Conclusions}

This paper has presented a test of the PIH with quadratic preferences and infinite horizon. I have shown that the availability of subjective income expectations and income realizations allows the exact identification of transitory and permanent income shocks if data are available for at least two consecutive time periods. Subjective income expectations are then used to test the hypothesis that households "save for a rainy day", e.g. that saving reacts exclusively to transitory shocks.

The empirical analysis rejects this simple version of the PIH. I have shown that when heterogeneity is accounted for, savings do react to transitory income shocks, but the magnitude of the effect is tiny, a finding that can be reconciled only with very high real interest rates or binding liquidity constraints. In addition, I have shown that the assumption of quadratic preferences is inappropriate: higher moments of the distribution of income should not matter but they do. This finding is supported by previous evidence, is in agreement with the existence of a precautionary motive for saving, and is consistent with the theoretical lack of plausibility of the assumption of increasing risk aversion implied by quadratic preferences. 


\section{References}

Alessie, Rob, and Annamaria Lusardi (1997), "Saving and income smoothing: Evidence from panel data", European Economic Review, 41, 1251-79.

Bertola, Giuseppe, and Andrea Ichino (1996), "Crossing the river: A comparative perspective of Italian employment dynamics", Economic Policy, 361-420

Blundell, Richard W., and Ian Preston (1998), "Consumption inequality and income uncertainty", forthcoming in Quarterly Journal of Economics

Brandolini, Andrea, and Luigi Cannari (1994), "Methodological Appendix", in Saving and the accumulation of wealth, Albert Ando, Luigi Guiso and Ignazio Visco, eds. (Cambridge: Cambridge University Press).

Browning, Martin, and Annamaria Lusardi (1996), "Household saving: Micro theories and micro facts", Journal of Economic Literature, 34, 1797-855

Caballero, Ricardo J. (1990), "Consumption puzzles and precautionary savings", Journal of Monetary Economics, 25, 113-36

Campbell, John Y. (1987), "Does saving anticipate declining labour income? An alternative test of the permanent income hypothesis", Econometrica, 45, $1249-73$

Chamberlain, Gary (1984), "Panel data", in Handbook of Econometrics, vol. 2, Zvi Griliches and Michael D. Intriligator, eds. (Amsterdam: North-Holland, Elsevier Science B.V.)

Deaton, Angus (1992a), "Saving and income smoothing in the Côte d'Ivoire", Journal of African Economics, 1, 1-24

Deaton, Angus (1992b), "Understanding consumption" (Oxford: Oxford University Press)

Flavin, Marjorie (1981), "The adjustment of consumption to changing expectations about future income", Journal of Political Economy, 89, 974-1009

Flavin, Marjorie (1993), "The excess smoothness of consumption: Identification and interpretation", Review of Economic Studies, 60, 651-66

Guiso, Luigi, Tullio Jappelli, and Daniele Terlizzese (1992), "Earnings uncertainty and precautionary saving", Journal of Monetary Economics, 30, 307-37

Guiso, Luigi, Tullio Jappelli, and Daniele Terlizzese (1994), "Why is Italy's saving rate so high?", in Saving and the accumulation of wealth. Essays on Italian households and government behavior, Albert Ando, Luigi Guiso and Ignazio Visco, eds. (Cambridge: Cambridge University Press) 
Hall, Robert E., and Frederic S. Mishkin (1982), "The sensitivity of consumption to transitory income: Estimates from panel data of households", Econometrica, 261-81

Jappelli, Tullio, and Luigi Pistaferri (1998), "Using subjective income expectations to test for the excess sensitivity of consumption to predicted income growth," forthcoming in European Economic Review

Kimball, Miles (1992), "Precautionary saving in the small and in the large", Econometrica, 58, 53-73

Miniaci, Raffaele, and Guglielmo Weber (1996), "The Italian recession of 1993: aggregate implications of microeconomic evidence". University of Padua, mimeo

Muth, J.F. (1960), "Optimal properties of exponentially weighted forecasts", Journal of the American Statistical Association, 45 
Table 1

THE EMPIRICAL DISTRIBUTION OF INCOME SHOCKS

\begin{tabular}{|c|c|c|c|}
\hline & $\begin{array}{c}\text { Average permanent } \\
\text { shock/earnings in } 1991\end{array}$ & $\begin{array}{l}\text { Transitory shock in } \\
\text { 1991/earnings in } 1991\end{array}$ & $\begin{array}{c}\text { Transitory shock in } \\
\text { 1989/earnings in } 1989\end{array}$ \\
\hline \multicolumn{4}{|l|}{ Age in 1991} \\
\hline$\leq 35$ & $\begin{array}{l}-0.0308 \\
(0.0154)\end{array}$ & $\begin{array}{c}0.0251 \\
(0.0046)\end{array}$ & $\begin{array}{l}-0.0009 \\
(0.0044)\end{array}$ \\
\hline $35-55$ & $\begin{array}{l}-0.0537 \\
(0.0110)\end{array}$ & $\begin{array}{c}0.0275 \\
(0.0034)\end{array}$ & $\begin{array}{c}0.0073 \\
(0.0021)\end{array}$ \\
\hline$>55$ & $\begin{array}{l}-0.0392 \\
(0.0098)\end{array}$ & $\begin{array}{c}0.0404 \\
(0.0041)\end{array}$ & $\begin{array}{c}0.0282 \\
(0.0031)\end{array}$ \\
\hline \multicolumn{4}{|l|}{ Education } \\
\hline Compulsory & $\begin{array}{l}-0.0374 \\
(0.0093)\end{array}$ & $\begin{array}{c}0.0345 \\
(0.0028)\end{array}$ & $\begin{array}{c}0.0218 \\
(0.0021)\end{array}$ \\
\hline High school & $\begin{array}{l}-0.0576 \\
(0.0114)\end{array}$ & $\begin{array}{c}0.0289 \\
(0.0048)\end{array}$ & $\begin{array}{c}0.0060 \\
(0.0029)\end{array}$ \\
\hline University & $\begin{array}{l}-0.0496 \\
(0.0194)\end{array}$ & $\begin{array}{c}0.0257 \\
(0.0077)\end{array}$ & $\begin{array}{l}-0.0080 \\
(0.0063)\end{array}$ \\
\hline \multicolumn{4}{|l|}{ Region } \\
\hline North & $\begin{array}{l}-0.0515 \\
(0.0102)\end{array}$ & $\begin{array}{c}0.0364 \\
(0.0042)\end{array}$ & $\begin{array}{c}0.0126 \\
(0.0028)\end{array}$ \\
\hline South & $\begin{array}{l}-0.0538 \\
(0.0115)\end{array}$ & $\begin{array}{c}0.0261 \\
(0.0027)\end{array}$ & $\begin{array}{c}0.0166 \\
(0.0025)\end{array}$ \\
\hline \multicolumn{4}{|l|}{ Occupation } \\
\hline Employed & $\begin{array}{l}-0.0288 \\
(0.0067)\end{array}$ & $\begin{array}{c}0.0297 \\
(0.0026)\end{array}$ & $\begin{array}{c}0.0092 \\
(0.0022)\end{array}$ \\
\hline Self-employed & $\begin{array}{l}-0.0865 \\
(0.0237)\end{array}$ & $\begin{array}{c}0.0304 \\
(0.0076)\end{array}$ & $\begin{array}{c}0.0085 \\
(0.0053)\end{array}$ \\
\hline \multicolumn{4}{|l|}{ Sector } \\
\hline Private & $\begin{array}{l}-0.0481 \\
(0.0093)\end{array}$ & $\begin{array}{c}0.0316 \\
(0.0029)\end{array}$ & $\begin{array}{c}0.0097 \\
(0.0028)\end{array}$ \\
\hline Public & $\begin{array}{l}-0.0439 \\
(0.0100)\end{array}$ & $\begin{array}{c}0.0338 \\
(0.0041)\end{array}$ & $\begin{array}{c}0.0080 \\
(0.0030)\end{array}$ \\
\hline
\end{tabular}


continue Table 1

\begin{tabular}{|c|c|c|c|}
\hline & $\begin{array}{c}\text { Average permanent } \\
\text { shock/earnings in } 1991\end{array}$ & $\begin{array}{l}\text { Transitory shock in } \\
\text { 1991/earnings in } 1991\end{array}$ & $\begin{array}{c}\text { Transitory shock in } \\
\text { 1989/earnings in } 1989\end{array}$ \\
\hline \multicolumn{4}{|l|}{ Family income } \\
\hline First quartile & $\begin{array}{l}-0.0769 \\
(0.0163)\end{array}$ & $\begin{array}{c}0.0312 \\
(0.0047)\end{array}$ & $\begin{array}{c}0.0263 \\
(0.0032)\end{array}$ \\
\hline Second quartile & $\begin{array}{l}-0.0443 \\
(0.0131)\end{array}$ & $\begin{array}{c}0.0313 \\
(0.0035)\end{array}$ & $\begin{array}{c}0.0155 \\
(0.0040)\end{array}$ \\
\hline Third quartile & $\begin{array}{l}-0.0311 \\
(0.0113)\end{array}$ & $\begin{array}{c}0.0317 \\
(0.0055)\end{array}$ & $\begin{array}{c}0.0062 \\
(0.0027)\end{array}$ \\
\hline Forth quartile & $\begin{array}{l}-0.0266 \\
(0.0131)\end{array}$ & $\begin{array}{c}0.0334 \\
(0.0047)\end{array}$ & $\begin{array}{c}0.0070 \\
(0.0034)\end{array}$ \\
\hline Whole sample & $\begin{array}{l}-0.0447 \\
(0.0068)\end{array}$ & $\begin{array}{c}0.0319 \\
(0.0023)\end{array}$ & $\begin{array}{c}0.0138 \\
(0.0017)\end{array}$ \\
\hline
\end{tabular}

Note: Standard errors are reported in parenthesis. 
TABLE 2

THE "SAVING FOR A RAINY DAY" EQUATION

(1)
(2)
(3)

(4)
(5)

\begin{tabular}{|c|c|c|c|c|c|}
\hline Transitory shock ${ }_{t}$ & $\begin{array}{c}0.7105 \\
(0.2632)\end{array}$ & $\begin{array}{c}1.2782 \\
(0.3038)\end{array}$ & $\begin{array}{c}0.7509 \\
(0.2566)\end{array}$ & $\begin{array}{c}0.4530 \\
(0.2179)\end{array}$ & $\begin{array}{c}0.4774 \\
(0.2153)\end{array}$ \\
\hline Permanent shock ${ }_{t}$ & & $\begin{array}{c}0.1528 \\
(0.0763)\end{array}$ & & & \\
\hline Conditional variance $_{t}$ & & & $\begin{array}{c}0.0012 \\
(0.0004)\end{array}$ & & $\begin{array}{c}0.0007 \\
(0.0004)\end{array}$ \\
\hline \# of observations & 2,204 & 1,102 & 2,204 & 1,102 & 1,102 \\
\hline $\mathrm{R}^{2}$ & 0.0085 & 0.0414 & 0.0156 & 0.0070 & 0.0117 \\
\hline
\end{tabular}

Note: The sample includes 1,044 heads ( 94.74 percent of the sample) and 58 (5.26 percent) spouses. Standard errors robust to heteroscedasticity of unknown form are reported in parenthesis. All regressions (except the ones in first-differences) include a constant. 
TABLE 3

THE "SAVING FOR A RAINY DAY" EQUATION: ACCOUNTING FOR PREFERENCE HETEROGENEITY

\begin{tabular}{|c|c|c|c|c|c|}
\hline & (1) & (2) & (3) & (4) & $(5)$ \\
\hline Transitory shock $_{t}$ & $\begin{array}{c}0.6673 \\
(0.2624)\end{array}$ & $\begin{array}{c}1.2531 \\
(0.2998)\end{array}$ & $\begin{array}{c}1.2566 \\
(0.2995)\end{array}$ & $\begin{array}{c}0.3918 \\
(0.2258)\end{array}$ & $\begin{array}{c}0.4147 \\
(0.2234)\end{array}$ \\
\hline Permanent shock $t$ & & $\begin{array}{c}0.1643 \\
(0.0750)\end{array}$ & $\begin{array}{c}0.1591 \\
(0.0745)\end{array}$ & & \\
\hline Conditional variance $_{t}$ & & & $\begin{array}{c}0.0011 \\
(0.0004)\end{array}$ & & $\begin{array}{c}0.0006 \\
(0.0004)\end{array}$ \\
\hline Age & $\begin{array}{c}452.47 \\
(109.27)\end{array}$ & $\begin{array}{c}520.27 \\
(146.35)\end{array}$ & $\begin{array}{c}504.64 \\
(145.90)\end{array}$ & $\begin{array}{c}11.22 \\
(23.03)\end{array}$ & $\begin{array}{c}10.37 \\
(23.07)\end{array}$ \\
\hline $\mathrm{Age}^{2}$ & $\begin{array}{l}-4.19 \\
(1.05)\end{array}$ & $\begin{array}{l}-4.71 \\
(1.37)\end{array}$ & $\begin{array}{l}-4.51 \\
(1.37)\end{array}$ & & \\
\hline Family size & $\begin{array}{c}767.10 \\
(218.46)\end{array}$ & $\begin{array}{l}1130.50 \\
(262.02)\end{array}$ & $\begin{array}{c}1159.41 \\
(260.04)\end{array}$ & $\begin{array}{l}2302.57 \\
(895.13)\end{array}$ & $\begin{array}{l}2223.11 \\
(898.83)\end{array}$ \\
\hline \# of observations & 2,204 & 1,102 & 1,102 & 1,102 & 1,102 \\
\hline $\mathrm{R}^{2}$ & 0.0261 & 0.0726 & 0.0788 & 0.0138 & 0.0177 \\
\hline
\end{tabular}

Note: The sample includes 1,044 heads (94.74 percent of the sample) and 58 (5.26 percent) spouses. Standard errors robust to heteroscedasticity of unknown form are reported in parenthesis. All regressions include a constant. 
TABLE 4

THE “SAVING FOR A RAINY DAY” EQUATION: SENSITIVITY ANALYSIS

\begin{tabular}{|c|c|c|c|c|c|c|}
\hline & \multicolumn{3}{|c|}{ Excluding those aged over 65} & \multicolumn{3}{|c|}{ Excluding the self-employed } \\
\hline & (1) & (2) & (3) & (1) & (2) & (3) \\
\hline Transitory shock $_{\mathrm{t}}$ & $\begin{array}{c}0.6197 \\
(0.2868)\end{array}$ & $\begin{array}{c}1.1565 \\
(0.3230)\end{array}$ & $\begin{array}{c}0.6598 \\
(0.2797)\end{array}$ & $\begin{array}{c}0.6127 \\
(0.2747)\end{array}$ & $\begin{array}{c}1.0677 \\
(0.3688)\end{array}$ & $\begin{array}{c}0.6261 \\
(0.2746)\end{array}$ \\
\hline Permanent shock ${ }_{t}$ & & $\begin{array}{c}0.1694 \\
(0.0832)\end{array}$ & & & $\begin{array}{c}0.1945 \\
(0.0724)\end{array}$ & \\
\hline Conditional variance $_{t}$ & & & $\begin{array}{c}0.0011 \\
(0.0005)\end{array}$ & & & $\begin{array}{c}0.0007 \\
(0.0004)\end{array}$ \\
\hline \# of observations & 1,834 & 899 & 1,834 & 1,800 & 903 & 1,800 \\
\hline $\mathrm{R}^{2}$ & 0.0069 & 0.0417 & 0.0136 & 0.0058 & 0.0272 & 0.0087 \\
\hline
\end{tabular}

Note: Standard errors robust to heteroscedasticity of unknown form are reported in brackets. All regressions include a constant. 